\title{
Promoting Brands Through Mascot Endorsers
}

\author{
Pavan Patil \\ Assistant Professor, Marketing Management, Government of Maharashtra's Sydenham \\ Institute of Management Studies, Research and Entrepreneurship Education (SIMSREE), \\ Church gate, Mumbai, Maharashtra 400020, India
}

\begin{abstract}
Promotion of brands by marketers is carried out with the help of advertising, sales promotion and different promotional tools. Promotion of brands by endorsing a famous personality is one of the prominent strategies followed by marketers nowadays. Companies sign contracts with celebrities for endorsement. Celebrities have mass appeal; they are popular and have other attributes which impacts customers. Movie actors, sportspersons are utilized as endorsers for promotion of brands. Apart from movie actors, sportspersons and other real celebrities, mascots are also utilized for it. Unlike real celebrities marketers need to bring in to existence mascots. So it becomes interesting to research regarding mascots for promotion. The work is exploratory in direction and selective examples are taken into consideration for analyzing. The work tries to identify mascots endorser associated with companies for promotion, identify brands and inception of these mascots. Study concludes that mascots are utilized by companies for promoting both brands belonging to product and service category since a long time ago; usage duration of mascot for promotion is longer in period and they can be studied as alternative endorsers to real celebrities for promotional purpose.
\end{abstract}

Keywords: Brand, Celebrity, Endorser, Mascot, Promotion

\section{Introduction}

Promotion of brands by marketers is carried out with the help of advertising, sales promotion and different promotional tools. Promotion of brands by endorsing a famous personality is one of the prominent strategies followed by marketers nowadays. Companies sign contracts with celebrities for endorsement. Celebrities have mass appeal; they are popular and have other attributes which impact customers. Movie actors, sportspersons are utilized as endorsers for promotion of brands. Apart from movie actors, sportspersons and other real celebrities, mascots are also utilized for it. Unlike real celebrities marketers need to bring in to existence mascots. Mascots are fictional celebrities (Persons, animals or cartoons) and in brand promotion they are utilized for associations. Mascots also perform important act in humanization of modern corporations and developing an emotion oriented bond among the brand and customer. A mascot could be an illustration of either a real or an imaginary character, it represent the brands and adds life to it. It is something between the brand's logo and a celebrity brand endorser ${ }^{[13]}$. As per the global social media monitoring software company Synthesio, fictional characters might be better spokespeople for brands than celebrities on social media sites. Pillsbury's mascot endorser Doughboy ranked first in mascot endorsers with $22.14 \%$ of total brands social media buzz; whereas Brand GoDaddy's celebrity endorser Dania Patrick captured $12.72 \%$ of total brands social media buzz ${ }^{[8]}$.

\section{Objectives:}

The main objective of the paper is to identify mascot associated with brands for promotion along with inception of them.

\section{Purpose of Research:}

The purpose of the work at the preliminary level is whether mascot could be potential alternative for endorsement to real celebrities. The study could be useful for marketers in deciding about promotion such alternative. Some marketers may not afford costly deals with top-notch real celebrities, brand mascots could be thought over by them.

\section{Review of Literature}

Pairoa \& Arunrungswied (2016) stated that celebrity and mascot endorser can effectively transfer their reputation to corporate image and can influence the customers to purchase the product ${ }^{[14]}$. Solanki \& Sheth (2016) found that for low involvement food 
product category, the impact of animated spokes characters and cartoon characters is more than that of celebrity ${ }^{[16]}$. Jose \& Saraswathiamma, (2014) concluded that cartoon characters associated with brands have a great influence in making the brand attractive to kids and brand promotion strategies involving prominent cartoon characters can create wonders for brands ${ }^{[12]}$. Mohanty (2014) states that mascot performs very insignificant act in generating awareness and preference regarding brand and concludes that for promoting brands it has utility. Developing a mascot or brand character can be an effective tool in building good advertisement and rapport with consumers ${ }^{[13]}$. Chiu \& Lin (2012) resulted that when customers become familiar with spokes-character and brand up to a specific mark, they influence each other and the relative familiarizing level will moderate the extent of the reciprocal influence ${ }^{[10]}$. Jain, Roy, Daswani, \& Mari (2011) states that fictional celebrity may have more impact in the case of high-involvement products ${ }^{[11]}$.

\section{Analysis of identification of Brand, Mascot and its inception}

5.1 Brand Michelin, Brand ambassador - Michelin Man, born in the year $1898^{[6]}$.

5.2 Brand Air India, Mascot - Maharaja, $1^{\text {st }}$ appeared in $1946^{[4]}$.

5.3 Brand Asian Paints, Mascot - Gattu, introduced in $1954^{[15]}$.

5.4 Brand Parle-G, Parle-G girl an illustration created in 1960's ${ }^{[1]}$.

5.5 Brand Pillsbury, Mascot-Doughboy, idea was born \& first commercial aired in $1965^{[7]}$

5.6 Brand Amul, Mascot - Amul Girl, created in the year $1966^{[2]}$.

5.7 Brand McDonald, Spokesperson \& ambassador-Ronald McDonald, named in 1967 [5].

5.8 Brand Onida, Mascot -Devil, created in 1980's ${ }^{[2]}$.

5.9 Brand Nirma, Mascot -The Nirma Girl was conceived in $1985^{[2]}$.

5.10 Brand PepsiCo 7UP, Mascot-Fido Dido, used for advertising in India in the year $1992^{[9]}$.

5.11 Brand Vodafone, Special character -Zoo zoo, birthed in the year $2009^{[3]}$.

It can be analyzed that marketers of products as well as services are using mascots to promote their brands and the inception of the above mentioned brands is a not recent one. It can also be analyzed that the usage duration of brand mascots for promotion is longer in timeframe.

\section{Findings}

The oldest one among the brand mascot considered in the study is found to be Michelin Man (1898) and the newest one is found to be Zoo zoo of Vodafone (2009). It is found that mascots are utilized for promoting products as well as services.

\section{Methodology}

Information for the said work is obtained through online search, websites and journal papers. Secondary sources are used for work and data is analyzed in qualitative manner. The study focuses on conveniently specified cases with an exploratory view.

\section{Limitations:}

The study is carried out for conveniently specified cases of brands, mascots. The work is exploratory in nature and not conclusive in manner based on primary data. The paper did not focus on effectiveness of these mascots concerning promotion and its past and present association and utilization status.

\section{Further research areas:}

Comparison between real celebrity endorser and mascot can be thought concerning effectiveness. A research focusing on a particular mascot associated with brand can also be useful.

\section{Implication:}

Practitioners can utilize the study for giving a thought to use mascots over real celebrities. It can be suggested to marketers who find celebrity brand endorsement costly, to consider and create mascots for promotion of their brands.

\section{Conclusion:}

It can be stated that mascot is utilized for promoting brands by companies since a long time ago and they can be further researched as alternative endorsers to real celebrities for promotional purpose. It can be stated that the duration of mascots for promotional purpose is longer in period.

\section{References}

[1]. (2013, October 30). Retrieved from https://economictimes.indiatimes.com: https://economictimes.indiatimes.com/slides hows/advertising-marketing/parle-g-thejourney-of-a-biscuit-formasses/slideshow/24923028.cms

[2]. (2017, October 10). Retrieved from https://www.adgully.com: 
https://www.adgully.com/most-iconicbrand-mascots-of-indian-advertising-andthe-stories-behind-them-74504.html

[3]. (n.d.). Retrieved from http://www.afaqs.com: http://www.afaqs.com/news/story/23893_Z oozoo-The-new-brand-endorser-forVodafone

[4]. (n.d.). Retrieved from http://www.airindia.in: http://www.airindia.in/the-air-indiabrand.htm

[5]. (n.d.). Retrieved from https://www.mcdonaldsindia.com: https://www.mcdonaldsindia.com/kidszone. html

[6]. (n.d.). Retrieved from https://www.michelin.i: https://www.michelin.in/auto/homeauto/the-michelin-man

[7]. (n.d.). Retrieved from https://www.pillsbury.com: https://www.pillsbury.com/doughboy

[8]. (n.d.). Retrieved from www.adweek.com: http://www.adweek.com/digital/mascotsgenerate-more-social-media-buzz-forbrands-than-celebrities-study-reveals/

[9]. (n.d.). Retrieved from www.pepsicoindia.co.in: http://www.pepsicoindia.co.in/brands/7up.h tml

[10]. Chiu, Y.-K., \& Lin, C.-Y. (2012). The Influence of Spokes-Characters on Consumer Patronage Intention. Asia Pacific Management Review, 421-435.
[11]. Jain, V., Roy, S., Daswani, A., \& Mari, S. (2011). What really works for teenagers: human o rfictional celebrity? YOUNG CONSUMERS Emerald Group Publishing Limited, 171-183.

[12]. Jose, A., \& Saraswathiamma, K. (2014). Effectiveness of Cartoon Character's in Creating Brand Preferences Among kids. Journal of Economic Development, Management, IT, Finance and Marketing, 61-76.

[13]. Mohanty, S. S. (2014). Growing Importance of Mascot \& their Impact on Brand Awareness - A Study of Young Adults in Bhubaneswar City. IJCEM International Journal of Computational Engineering \& Management, 42-44.

[14]. Pairoa, I., \& Arunrungswied, P. (2016). An overview on the effectiveness of Brand Mascot and Celebrity Endorsement. International Journal of Economics and Management Engineering, 3821-3827.

[15]. Pinto, V. S. (2015, February 12). Retrieved from http://www.businessstandard.com: http://www.businessstandard.com/article/management/40-yearsago-and-now-gattu-s-antics-coloured-asianpaints-future-115021201710_1.html

[16]. Solanki , S. P., \& Sheth, B. H. (2016). Effectivenees of Advertisements: A Study On Comparitive Analysis of Celebrityendorsed Advertisements versus Animatedcharacter-endorsed Advertisements for Children. Rupkatha Journal on Interdisciplinary Studies in Humanities, 308-320. 